\title{
Original
}

\section{Plant Defense System Activated in Chili Plants by Using Extracts from Eucalyptus citriodora}

\author{
SOBIYA SHAFIQUE ${ }^{1 *}$, SHAZIA SHAFIQUE ${ }^{1}$, MARIAM ZAMEER $^{2}$, \\ AND MUHAMMAD ASIF ${ }^{1}$ \\ 1'Institute of Agricultural Sciences, University of the Punjab, Quaid-e-Azam Campus, Lahore 54590, Pakistan \\ ${ }^{2}$ College of Earth and Environmental Sciences, Quaid-e-Azam Campus, Lahore 54590, Pakistan \\ Received 19 September, 2018/Accepted 1 March, 2019
}

\begin{abstract}
Capsicum annuum L. is infected by Fusarium Wilt and causes significant yield losses in Pakistan. Biological control is an excellent and environment friendly way. Presently, the biocontrol assays were conducted in pot trials using methanolic leaf extract of Eucalyptus citriodora L. where spray of extract prior to infection provided better protection from pathogen with maximum disease control. Further, Native page electrophoresis was performed to find out difference in expression profile of enzyme which revealed that control and T2 (Plant sprayed with Eucalyptus extract) did not exhibit any difference in their isozyme profile signifying no extra load of biological control measure on plant for the production of defense elements until the pathogen arrived. While in case of T3 (Protective treatment) and T4 (Curative treatment) extra isozyme (P01) was observed in T4 only, PPO1 and PPO5, and PAL 2 and PAL 3 were comprised in higher quantities in T3 and T4 over control exposing the expression of plant metabolism under pathogen attack. The study concludes that the organic extract of $E$. citriodora have the potential to restrain the disastrous effects of pathogenic fungi. It will lead to the different aspect of biocontrol to suppress the plant pathogenic fungi in a broad spectrum.
\end{abstract}

Key words : Capsicum annuum / Defense related enzymes / Eucalyptus citriodora / Induced resistance.

\section{INTRODUCTION}

Biological control using plant extracts provides an effective fungal management program, and represents an alternative to reliance on fungicides (Bowers and Locke, 2004). It is often used to gradually suppress widespread infestations in low value or remote areas where other methods are not feasible. Studies on the mechanisms of disease control by plant extracts/products have revealed that the biologically active constituents present in them may have either direct antimicrobial activity (Ansari, 1995; Amadioha, 2000) or induce host plants defense response resulting in reduction of disease development (Schneider and Ullrich, 1994). Induced resistance is an important component of disease-resistance response of plants, and is accompanied by increased capability for activating defense

\footnotetext{
*Corresponding author. Tel: +92-42-99231846, E-mail : sobiya.iags (a)pu.edu.pk
}

responses upon pathogen ingress. In fact, the induction of resistance in plants involves the activation of defense latent mechanisms in response to the treatment with elicitor agents (plant secondary metabolites), protecting against the subsequent infection by pathogens (Kagale et al., 2004). There are many reports in the literature which demonstrate the concept of induced resistance in laboratory or glasshouse experiments, including biotic and abiotic elicitors, either in a pure form or as a crude mixture. The defense gene products include peroxidase (PO), polyphenol oxidase (PPO) that catalyze the formation of lignin and phenylalanine ammonia-lyase (PAL) that is involved in phyto-alexins and phenolics synthesis. Other defense enzymes include pathogenesis-related proteins (PRs) such as $\beta$-1,3-glucanases (PR-2 family) and chitinases (PR-3 family) which degrade the fungal cell wall and cause lysis of fungal cell. Chitin and glucan oligomers released during degradation of fungal cell wall act as elicitors that elicit various defense mechanisms in the plants (Frindlender et al., 
1993). Induction of defense proteins has been correlated with defense against pathogen invasion in cucumber (Rasmussen, 1991), green gram (Ramanathan et al., 2000), tobacco (Beaudoin-Eagan and Thorpe, 1985) and tomato (Bashan et al., 1985).

Eucalyptus citriodora, called lemon-scented eucalyptus, is a diverse genus of trees in the family Myrtaceae. It is an evergreen tree, important to get rid of fungus, and very antiseptic. Recently, attention has been focused on the medicinal properties of its extracts. In supplement, the trees have been known to fabricate several natural substances having antagonistic activities against several microorganisms (Mireku and Wilkes, 1988; Lee and Shibamoto, 2001). Research data has demonstrated that the extracts exhibited various biological effects, such as antibacterial, antihyperglycemic (Gray and Flatt, 1998) and antioxidant (Lee and Shibamoto, 2001) activities. Therefore, the aim of this research was to study the expression of defense related enzymes and the measurement of physiological parameters after induction of resistance in chili by using extracts of Eucalyptus citriodora.

\section{METERIALS AND METHODS}

Preparation of Conidial suspension and Plant Extract:

The four pure cultures of Fusarium oxysporum were isolated from the diseased chili plant (grown in experimental station of Institute of Agricultural Sciences, PU, Lahore) on PCNB medium and labeled as F. oxysproum A, F. oxysproum B, F. oxysproum C and F. oxysproum D. PCNB medium was composed of Part 1: Distilled Water $1 \mathrm{~L}$, difco Peptone $15 \mathrm{~g}, \mathrm{~K}_{2} \mathrm{HPO}_{4} 1 \mathrm{~g}, \mathrm{MgSO}_{4}$. $7 \mathrm{H}_{2} \mathrm{O} 0.5 \mathrm{~g}$, Agar $15 \mathrm{~g}$, PCNB (Terraclor $75 \%$ WP) (Pentachloronitrobenzene) $1.0 \mathrm{~g}$. Part 2: Streptomycin $0.3 \mathrm{~g}$, Neomycine Sulfate $0.12 \mathrm{~g}$. All these ingredients of part 1 were mixed and autoclaved at $121^{\circ} \mathrm{C}$ and $15 \mathrm{lb}$ inch $^{-2}$ pressure for $30 \mathrm{~min}$. The medium was allowed to cool to $50-55^{\circ} \mathrm{C}$ and the ingredients of part 2 were added in it. All the cultures were maintained on $2 \%$ malt extract agar (MEA) medium in petri plates by using

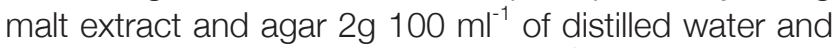
autoclaved at $121^{\circ} \mathrm{C}$ and $15 \mathrm{lb}$ inch $^{-2}$ pressure for 30 min. They were sub cultured to make pure cultures for further use and stored at $4^{\circ} \mathrm{C}$. F. oxysporum strain B was the most pathogenic hence used in subsequent studies. Conidial suspension of $F$. oxysporum strain B (4 $\times 10^{5}$ conidia per $\mathrm{mL}$ ) was prepared by using the protocol of French and Hebert (1982).

Fresh leaves of $E$. citriodora were collected from Quaid-e-Azam campus, University of the Punjab, Lahore in December, 2012, washed, and grinded to make powder. Then methanolic plant extract was prepared by using the protocol of Javaid and Munir
(2012). Hundred grams (100 g) of dried and powdered material of $E$. citriodora leaves were soaked in $1000 \mathrm{~mL}$ methanol for one month. After one month, materials were filtered through muslin cloth followed by filtration through filter paper. The filtrates were evaporated under vacuum in a rotary evaporator at $45^{\circ} \mathrm{C}$ to yield $18.01 \mathrm{~g}$ of crude methanolic extract of leaf. Then, this methanolic extract was dissolved in sterilized water to prepare 60 $\mathrm{mL}$ of stock solution.

\section{Pot Trials}

The in vivo efficacy of selected plant was investigated prior (Protective potential) and after the pathogen inoculum (Curative potential) of $F$. oxysporum strain B using pot trials. The pot trials were designed in a completely randomized design in 3 sets in triplicate.

\section{Protective Potential of E. citriodora}

Chili plants were grown in pots under controlled environment of green house and one month old plants were sprayed with five $\mathrm{mL}$ of leaf methanolic extract of $E$. citriodora of different concentrations i.e. 5, 7 and $9 \%$. After 3 days, $3 \mathrm{~mL}$ of fungal inoculum containing $4 \times 10^{5}$ conidia per $\mathrm{mL}$ was also applied to same plants. The plants were covered with polythene bags and were irrigated with tap water when needed. After the incubation period of two weeks disease symptoms, \% age disease index and \%age control was recorded.

Percentage control $=100-$ Percentage disease index

\section{Curative Potential of E. citriodora}

Chili plants of one month of age were sprayed with 3 $\mathrm{mL}$ of fungal inoculum containing $4 \times 10^{5}$ conidia per $\mathrm{mL}$ under the green house conditions. Pathogen was allowed to establish for 3 days prior to application of five $\mathrm{mL}$ of leaf methanolic extract of $E$. citriodora of different concentrations i.e. 5, 7 and 9\%. The plants were covered with polythene bags and were irrigated with tap water when needed. Then, after ten days of spray \%age disease index and percentage control was calculated for each concentration.

\section{Isozyme studies}

To evaluate the isozyme pattern of different defense related enzymes screened out samples from protective and curative assays were subjected to Native PAGE electrophoresis by using following protocol of Goldenburg (1989) and Moeen et al. (2014).

\section{Staining of peroxidase (PO)}

The isozyme bands of peroxidase were localized by incubating the gel in Guiacol reagent $(0.25 \%)$ for 30 min followed by incubation in $0.3 \%$ hydrogen peroxide 
for 15 min which showed the appearance of bands of peroxidase enzyme. The migration distance of each band and tracking dye was recorded. The migration distances were expressed as the ratio of the migration distance of isozyme to the tracking dye. This factor is known as relative mobility and calculated as followed:

$$
\mathrm{Rm}=\frac{\text { Distance traveled by the isozyme }(\mathrm{cm})}{\text { Distance traveled by the tracking dye }(\mathrm{cm})}
$$

Using the Rm values, zymograms were also prepared pictorially.

\section{Polyphenol oxidase (PPO)}

Then for the detection of isozyme of polyphenol oxidase, the electrophorated gel was incubated in 0.03 $\mathrm{M}$ catechol containing $0.05 \%$ P-Phenylenediamine in acetate buffer ( $\mathrm{pH}$ 6.0) for 1 hour. The localized PPO bands were observed and the calculations of $\mathrm{Rm}$ values were made using the same formula as that of peroxidase isozyme.

\section{Phenylalanine ammonia lyase (PAL)}

The isozyme of phenylalanine ammonia lyase were stained by incubating the gels in 1\% ABTS solution [2,2'-azino-bis (3-ethylbenzothiazoline-6-sulphonic acid)] in sodium citrate buffer ( $\mathrm{pH} \mathrm{6.0)} \mathrm{for} 6$ hours. Observations and calculations of $\mathrm{Rm}$ values were performed as that of peroxidase isozyme.

\section{Statistical Analysis}

The data pertaining to various experiments was subjected to statistical analysis using methods described by Steel and Torrie (1980) and the differences among the treatment means were compared by using Duncan's Multiple Range Test (DMRT). The image analysis of isozyme study was carried out through GELANALYZER software (Onofri, Italy).

\section{RESULTS}

\section{Protective and Curative Assays}

Percentage Disease Control

It is exhibited from the results that evaluation of protective potential of methanolic leaf extract from fungal pathogen presented healthy results with a significant protection of chili plants at $9 \%$ concentration followed by 7 and 5\% (Fig. 1 and 2). The 9\% concentration protected plants with maximum disease control of about $85 \%$ and it was found to be decreased with decreasing concentration.

In case of curative bioassays, again ascending pattern of disease control was attained with maximum curative activity at $9 \%$ concentration with approximately

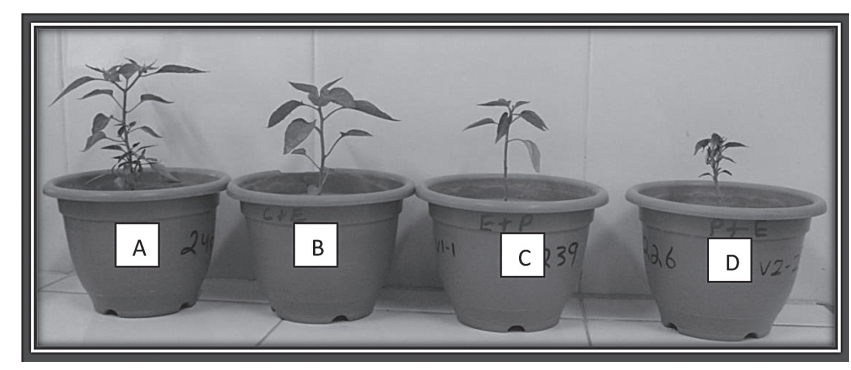

FIG. 1. Comparison of protective and curative treatments of $7 \%$ methanolic leaf extract of Eucalyptus citriodora.

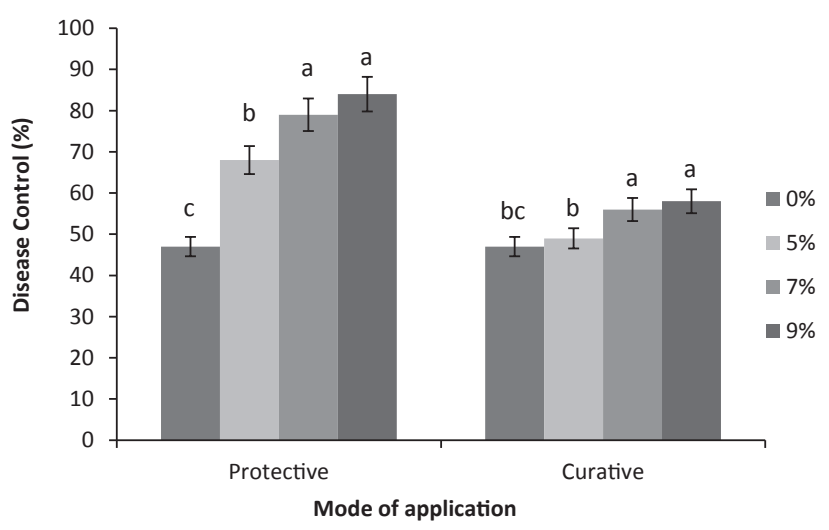

FIG. 2. Effect of protective and curative treatment of methanolic leaf extract of Eucalyptus citriodora on percentage disease control of Capsicum annuum.

Vertical bars indicate standard error of means of three replicates. Values with different letters show significant difference $(p \leq 0.05)$ as determined by Duncan's multiple range (DMR) test.

$58 \%$ disease control (Fig. 1). Curative ability of $7 \%$ concentration was found to be second among all the treatments used with an insignificant disease control of about 55\%.

The complete comparative analysis of protective and curative activity revealed that application of extract prior to pathogenic infection was the best strategy to control the disease (Fig. 1).

\section{Effect on Root Length}

The data regarding the efficacy of methanolic leaf extract of E. citriodora in protective and curative trials against $F$. oxysporum revealed that the extract exhibited significant defensive role and $F$. oxysporum induced less inhibitory results in suppressing the root length of chili plant in protective assays as compared to curative bioassays. About 50\% reduction in root length was noticed due to the activity of pathogen in curative assays. The positive control (only spray of $E$. citriodora on chili plant) displayed negligible and insignificant 


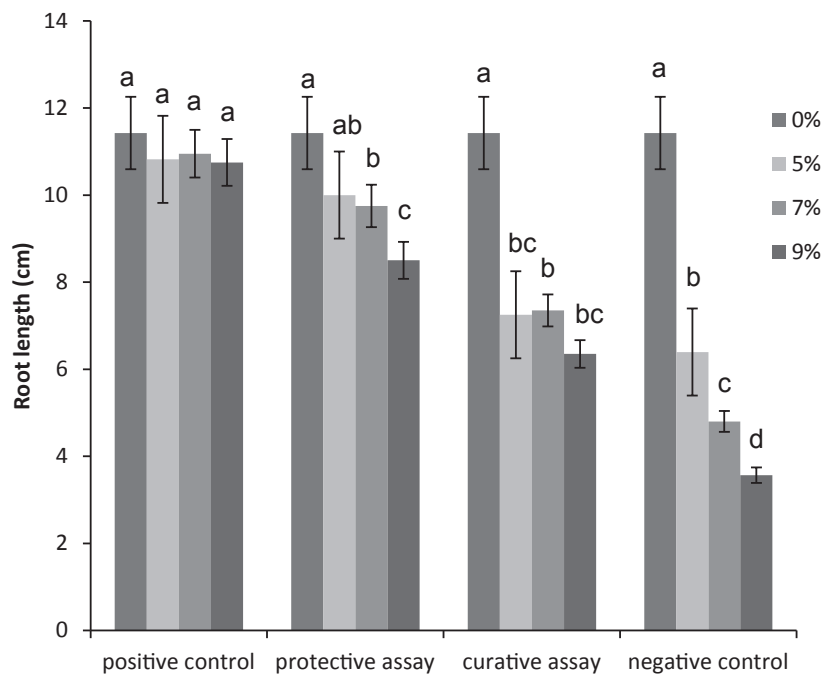

FIG. 3. Effect of protective and curative treatment of methanolic leaf extract of Eucalyptus citriodora on root length of Capsicum annuum.

Vertical bars indicate standard error of means of three replicates. Values with different letters show significant difference $(p \leq 0.05)$ as determined by Duncan's multiple range (DMR) test.

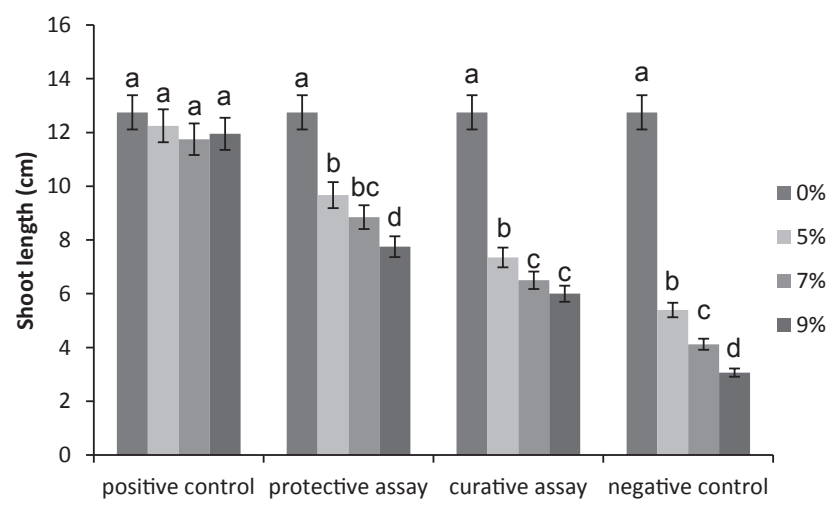

FIG. 4. Effect of protective and curative treatment of methanolic leaf extract of Eucalyptus citriodora on shoot length of Capsicum annuum.

Vertical bars indicate standard error of means of three replicates. Values with different letters show significant difference $(p \leq 0.05)$ as determined by Duncan's multiple range (DMR) test.

effect on root length (Fig. 3). Whereas the negative control (only pathogen) depicted maximum arrest in root length (about 68\%).

\section{Effect on Shoot Length}

The data on shoot length of chili plant revealed that the shoot length of seedlings was not as severely affected by pathogenic attack in protective assays as compared to curative assays with reference to negative

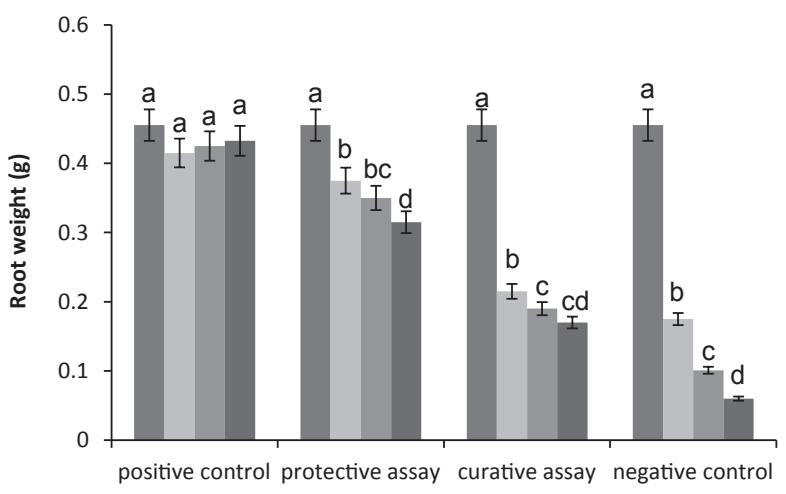

FIG. 5. Effect of protective and curative treatment of methanolic leaf extract of Eucalyptus citriodora on root weight of Capsicum annuum.

Vertical bars indicate standard error of means of three replicates. Values with different letters show significant difference $(p \leq 0.05)$ as determined by Duncan's multiple range (DMR) test.

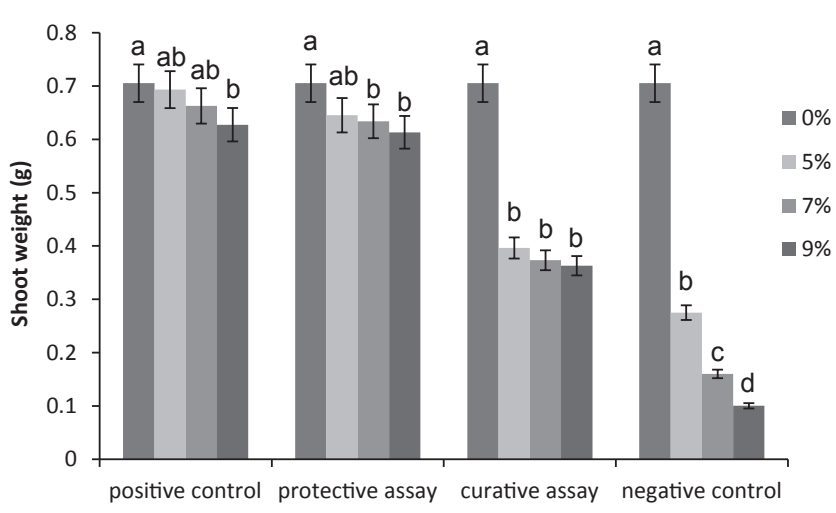

FIG. 6. Effect of protective and curative treatment of methanolic leaf extract of Eucalyptus citriodora on shoot weight of Capsicum annuum.

Vertical bars indicate standard error of means of three replicates. Values with different letters show significant difference $(p \leq 0.05)$ as determined by Duncan's multiple range (DMR) test.

control (Fig. 4). The growth of shoot length followed the same pattern of reduction with increase in concentration as the root length. The protective measure proved more effective as it depicted $24-40 \%$ suppression in shoot length while in curative activity the pathogen retarded the plant growth up to $42-53 \%$.

\section{Effect on Root Weight}

The data on root weight analysis revealed the same pattern and almost similar level of effects of various concentrations of leaf extract as on previously mentioned parameters of plant growth (Fig. 5). It was evident from the results that the level of inhibition in root weight was highly pronounced under the influence of 


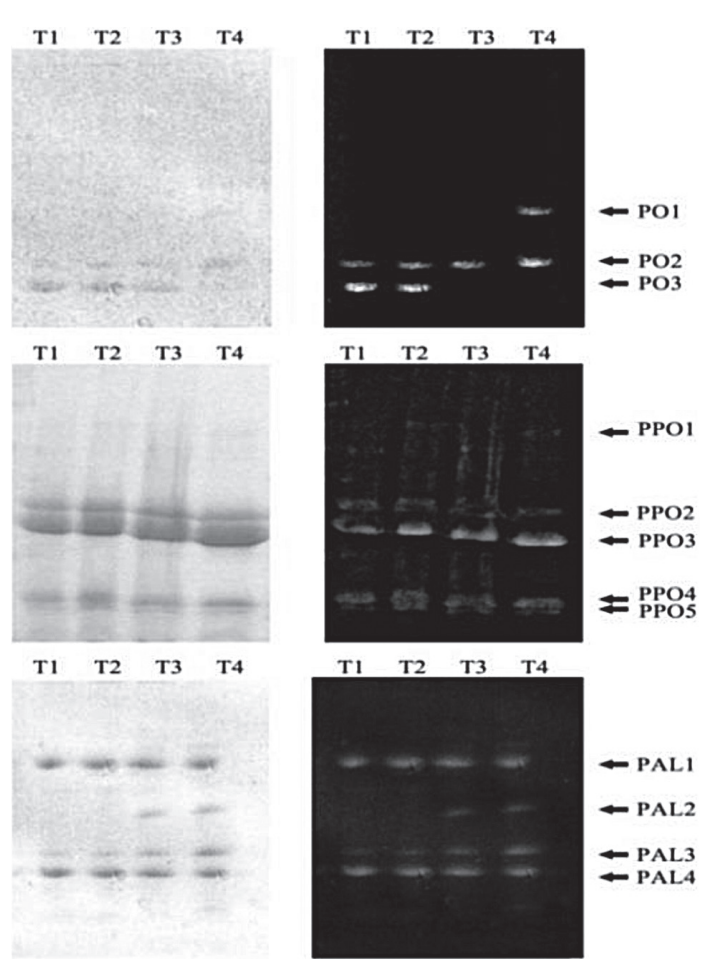

FIG. 7. Native-PAGE analysis for defense related enzymes isoforms profile induced by $E$. citriodora in $C$. annuum challenged with or without F. oxysporum. ( $T$ 1) Control plants- $C$. annuum. (T 2) Plants sprayed with extract of E. citriodora. (T 3) Plants sprayed with extract of $E$. citriodora prior to inoculation with F. oxysporum. (T 4) Plants challenged with F. oxysporum prior to spray of $E$. citriodora.

pathogenic attack in negative control and prior to the application of additive test plant extract (curative assays). A statistically significant and highly deficient growth of about $0.17 \mathrm{~g}$ was attained at $9 \%$ concentration in curative assays. While the additive extract suppressed the pathogen to cause infection in protective treatment and displayed comparatively more vigorous growth $(0.315 \mathrm{~g})$ in protective assay.

\section{Effect on Shoot Weight}

The data regarding shoot biomass, exposed to various concentrations of methanolic leaf extract of $E$. citriodora prior and after the pathogenic attack is portrayed in Fig. 6. The shoot biomass was found to be affected by all the concentrations of allelopathic spray and dosage effect was clearly evident. However, the effect was not statistically significant among the varying concentrations. The protective application of extract exhibited more promising results in suppressing the pathogenic influence and host plant growth was well protected as it paraded 0.613-0.645g shoot biomass. While in curative treatment, $44-49 \%$ reduction in shoot weight was observed that revealed the severity of pathogen prior to

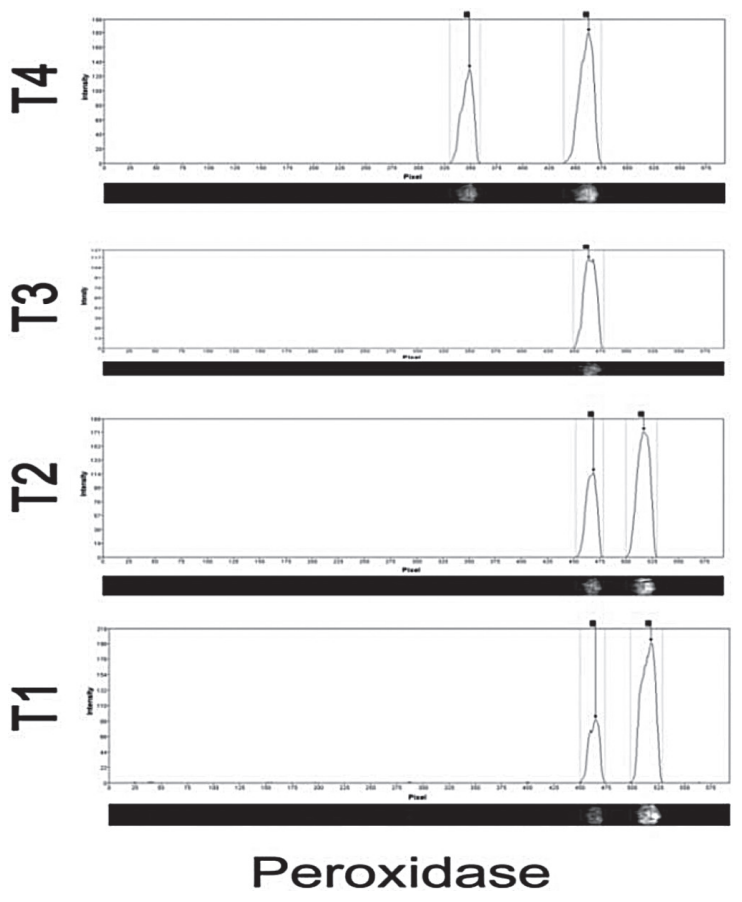

FIG. 8. Graph of electrophorated bands of peroxidase enzyme based on pixel intensity.

application of additive extract.

\section{Evaluation of Isozyme Pattern}

Native PAGE was performed to separate isozymes of different defense related enzymes (Fig. 7-10). A total of four isozymes were observed when gel was stained for $\mathrm{PO}$ isozymes. Two isozymes of $\mathrm{PO}$ viz; ( $\mathrm{PO} 2$ and $\mathrm{PO} 3$ ) were observed in control treatments. One extra isozyme (P01) was observed in T4 only. This indicates the modulation of plant metabolism under the attack of pathogen in the absence of biological control measure. On the other hand, isozyme "PO2" was more intense in T4 as compared to all other treatments. It was the most prominent and clear in T4 only. Prominent change was observed in T4 due to the activation of novel PO isozyme (Fig. 7 and 8 ).

In most of the cases of PPO, four isozymes were present out of the total five isozymes observed viz., (PPO1-5). Control treatment comprised 3 isozymes (PPO2, PPO3 and PPO4). T2 was the control treatment having just test plant material with eucalyptus extract and T4 had a treatment of pathogen+ plant extract. In T3 and T4 a total of 4 bands were observed, which was a clear difference as compared to the control treatment. The protective treatment had a one lesser isozyme than curative treatments with reference to its PPO isozyme profile, but it had an extra isozyme species than control treatment. Extra PPO isozymes in T4 clearly reveal the induction of stress metabolism in 

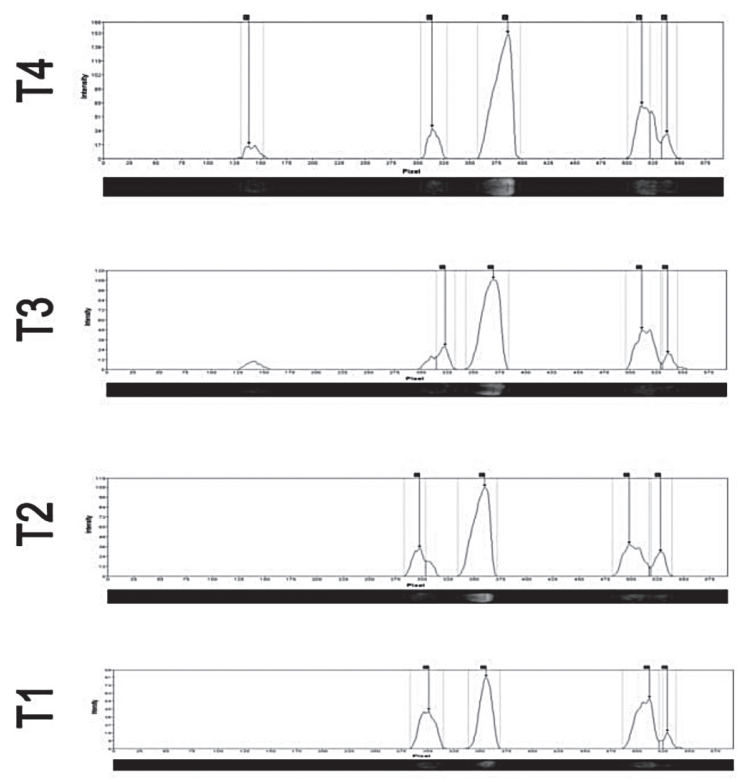

\section{Polyphenol oxidase}

FIG. 9. Graph of electrophorated bands of polyphenol oxidase enzyme based on pixel intensity.

plants stimulated by the biological agents. Moreover, the bands were thick and more visible in T4 treatment than T3 (Fig. 7 and 9).

In case of PAL (phenylalanine ammonia lyase) four isozymes were observed viz; (PPL1-4). Control treatment was comprised of only two bands, while in T3 (plant extract + pathogen) and T4 (pathogen + plant extract) two bands, which were distinguishably differentiated from the control treatment. Furthermore, control and T2 treatment had no difference in their PAL profile, which indicates that, the application of measure. citriodora leaf extract did not put extra burden on plant for the production of defense elements until the pathogen arrived. T4 comprised of higher quantities of PAL isozymes as compared to the control treatment. It was also notable that the T3 and T4 treatments had similar PAL profiling which was the indication of no differential enhancement in PAL isozymes by changing the application order of pathogen and biocontrol treatment but was only affected by the attack of pathogen (Fig. 7 and 10).

The results (Fig. 7-10) made obvious that the number and intensity of defense enzymes was increased after pathogen attack. Thus significantly higher quantities of defense related proteins i.e., PO, PPO and PAL in pathogen infested tissues confer stronger resistance. Therefore, their increase quantities can be easily justified the enhanced plant resistance against pathogen These enzymes can also be used as resistance describing parameters of plants.
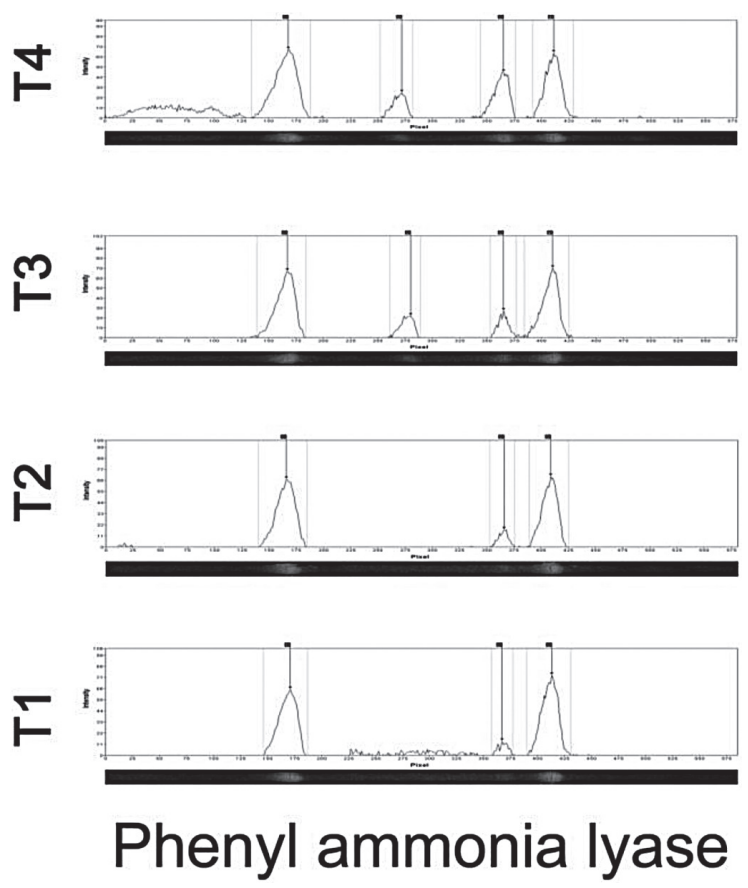

FIG. 10. Graph of electrophorated bands of phenyl ammonia lyase enzyme based on pixel intensity.

\section{DISCUSSION}

It is normally considered that the plant derived extracts or essential oils are a mixture of secondary metabolites (Liu et al., 2010), the importance of these agents is not only for the inhibitory effect on the pathogen, but in way due to their ability to induce host resistance may be by increasing the activity of enzymes which play a defense role against invading pathogens (Caruso et al., 2001; Nawar and Kuti, 2003). In the present study, for evaluating the biocontrol potential of E. citriodora leaf extract prior and after the pathogen inoculum; the study was conducted in pots trials. E. citriodora extract treatment enhanced the intensity of natural defenses of the host plant. It is revealed from the study that application of extract prior to pathogenic infection provided a significant resistance for pathogen to flourish and the plant was able to avoid the attack of pathogen hence the incidence of disease was reduced. Thus the maximum disease control up to $85 \%$ was recorded in protective trials. In case of curative assays, the disease control behavior of $E$. citriodora was less effective however it significantly managed pathogen attack as compared to control. In a contemporary study Hemdan et al. (2012) also concentrated upon evaluation of antifungal potential of plant derived agents i.e., extracts and essential oils against Erysiphe cichoracearum, the causal pathogen of okra powdery mildew. They reported that in detached leaf-disk assay, the highest preventative 
effect ( $97.74 \%$ ) was recorded by neem seed oil followed by jojoba oil (89.82\%) and extract of Rynoutria sachalinensis (82.77\%). Neem seed oil at 1\% was the most effective agent where it suppressed E. cichoracearum completely. Potted plants assay revealed that neem seed oil, jojoba oil and extract of $R$. sachalinensis as well as the fungicide (dinocap) showed higher preventative efficacy after 7 and 14 days of inoculation as compared to curative assays.

Furthermore, in present study the use of plant extracts represents an important module of disease-resistance response of plants, and is complemented by increased proficiency for activating defense responses upon pathogen ingress. The native gel analysis of isozyme profile presented markedly increased quantity of $\mathrm{PO}$, PPO and PAL when chili plant is inoculated with pathogen. The isozyme study revealed that after the attack of pathogen, the plants (T3 and T4) produced more isozymes as compared to remaining. It suggested a direct correlation between plant resistance and defense related enzymes. This is in agreement with the work conducted by Averyanov and Lapikova (1995) where isozyme studies were executed in response to fungal pathogenesis process. Results indicated that extra isozymes are expressed in protective treatment against pathogen invasion. In another research Luthra et al. (1988 similarly reported an active role of phenols and oxidizing enzymes such as PPO in resistance mechanism of plant diseases.

Contemporary, Guleria and Kumar (2006) in their study evidenced that aqueous leaf extract of neem (Azadirachta indica Juss.) provided the control of Alternaria leaf spot pathogen (Alternaria sesami) of sesame (Sesamum indicum L: Syn. S. orientale L). Treatment with this extract exhibited changes in plant metabolism as leaves of the treated plants showed significantly high level of enzymes phenylalanine ammonialyase (PAL), peroxidase (PO) and content of phenolic compounds. Furthermore, germination of $A$. sesami spores was not significantly inhibited by neem extract suggesting that, protection of sesame plants against $A$. sesami by neem extract might be due to stimulation of plants natural defense response.

Thus the evidence obtained from the bioassays in present study suggested that plant metabolites are the precious blessings of nature for disease management and act as defense weapons that may enable the plants to stand against the most devastating pathogens. Further the compounds responsible for the preventative and curative effects can be isolated from these agents in relation to host resistance in later study.

\section{REFERENCES}

Amadioha, A. C. (2000) Controlling rice blast in vitro and in vivo with extracts of Azadirachta indica. Crop Prot., 19, 287-290.

Ansari, M. M. (1995) Control of sheath blight of rice by plant extracts. Ind. Phytopathol., 48, 268-270.

Averyanov, A. A. and Lapikova, V. P. (1995) Peroxidase activity of excretions of healthy and blast infected rice leaves. Biol. Sci., 34, 81-82.

Bashan, Y., Okon, Y. and Henis, Y. (1985) Peroxidase, polyphenol oxidase and phenols in relation to resistance against Pseudomonas syringae pv. tomato in tomato. Can. J. Bot., 65, 366-372.

Beaudoin-Eagan, L. D. and Thorpe, T. A. (1985) Tyrosine and phenylalanine ammonia-lyase activities during shoot initiation in tobacco callus cultures. Plant Physiol., 78, 438441.

Bowers, J. H. and Locke, J. C. (2004) Effect of formulated plant extracts and oils on population density of Phytophthora nicotianae in soil and control of Phytophthora blight in the greenhouse. Plant Dis., 88, 11-16.

Caruso, C., Chilosi, G., Leonard, L., Bertin, L., Magro, P., Buonocore, V. and Caporal, C. (2001) A basic peroxidase from wheat kernel with antifungal activity. Phytochem., 58, 743-750.

French, E. R. and Hebert, T. T. (1982) Phytopathological Research Methods. IICA. San Jose Costa Rica, 275.

Frindlender, M., Inbar, J. and Chet, I. (1993) Biological control of soilborne plant pathogens by a $\beta-1,3-$ glucanase producing Pseudomonas cepacia. Soil Biol. Biochem., 25, 1211-1221.

Goldberg, G. I., Marmer, B. L., Grant, G. A., Eisen, A. Z., Wilhelm, S. and He, C. (1989) Human 72-kilodalton type IV collagenase forms a complex with a tissue inhibitor of metalloproteases designated TIMP-2. Proc. Nat. Acad. Sci. USA., 86, 8207-8211.

Gray, A. M. and Flatt, P. R. (1998) Antihyperglycemic actions of Eucalyptus globulus (eucalyptus) are associated with pancreatic and extra-pancreatic effects in mice. J. Nut., 128, 2319-2323.

Guleria, S. and Kumar, A. (2006) Azadirachta indica leaf extract induces resistance in sesame against Alternaria leaf spot disease. J. Cell Mol. Biol., 5, 81-86.

Javaid, A. and Munir, R. (2012) Bioassay guided fractionation of Withania somnifera for the management of Ascochyta rabiei. Int. J. Agri. Biol., 1, 797-800.

Kagale, S., Marimuthu, T., Thayumanavan, B., Nandakumar, R. and Samiyappan, R. (2004) Antimicrobial activity and induction of systemic acquired resistance in rice by leaf extract of Datura metel against Rhizoctonia solani and Xanthomonas oryzae pv. oryzae. Physiol. Mol. Plant Pathol., 65, 91-100.

Lee, K. G. and Shibamoto, T. (2001) Inhibition of malon aldehyde formation from blood plasma oxidation by aroma extracts and aroma components isolated from clove and eucalyptus. Food Chem. Toxicol., 39, 1199-1204.

Liu, F., Zhuge, Y. Y., Yang, C. Y., Jin, S. X., Chen, J., Li, H. and Dal, G. H. (2010) Control effect of some plant extracts against powdery mildew (Sphaerotheca fuligunea) and their stability study. Eu. J. Hort. Sci., 75(4), 147-152.

Luthra, Y. D., Joshi, U. M., Gandhi, S. K. and Arora, S. K. (1988) Biochemical alterations in downy mildew infected Lucerne leaves. Ind. Phytopathol., 41,100-106.

Mireku, E. and Wilkes, J. (1988) Production of phenols in the sapwood of Eucalytus maculata after wounding and infec- 
tion. Europ. J. Plant pathol., 18, 121-127.

Moharam, M. H. A. and Obiadalla Ali, H. A. E. (2012) Preventative and curative effects of several plant derived agents against powdery mildew disease of Okra. Not. Sci. Biol., 4(3), 76-82.

Moeen, R., Akram, W. and Anjum, T. (2014) Biochemical and molecular basis of resistance in sorghum against Curvularia leaf spot. Int. J. Agric. Biol., 16, 917-922.

Nawar, H. F. and Kuti, J. D. (2003) Wyerone acid phytoalexin synthesis and peroxidase activity as markers for resistance of broad beans to chocolate spot disease. J. Phytopathol., 151, 564-570.

Ramanathan, A., Samiyappan, R. and Vidhyasekaran, P. (2000) Induction of defense mechanisms in green gram leaves and suspension cultured cells by Macrophomina phaseolina and its elicitors. J. Plant Dis. Protect., 107, 245-257.

Rasmussen, J. B. (1991) Systemic induction of salicylic acid accumulation in cucumber after inoculation with Pseudomonas syringae pv syringae. Plant Physiol., 97, 1342-1347.

Schneider, S. and Ullrich, W. R. (1994) Differential induction of resistance and enhanced enzyme activities in cucumber and tobacco caused by treatment with various abiotic and biotic inducers. Physiol. Mol. Plant Pathol., 45, 291-304.

Steel, R. G. D. and Torrie, J. H. (1980) Principles and procedures of statistics. A Biometrical Approach. $2^{\text {nd }}$ edition. McGraw Hill Book Co. Inc. New York. USA. 